\title{
Improving Efficiency and TFP of Lowland Paddy Rice Farmers in Kwara State
} of Nigeria

\author{
M. S. Sadiq ${ }^{1 * 2}$, I. P. Singh ${ }^{1}$, N. K. Singh ${ }^{1}$ and G. M. Yakubu ${ }^{2}$ \\ Received: $12^{\text {th }}$ November $2017 /$ Accepted: 07th March 2018
}

\begin{abstract}
Purpose: The pressure on land for agricultural purposes is on the rise and sustainable agriculture remains the panacea for herdsmen attack on arable crop farmers in the study area. The present research empirically measured and identified the factors that influenced efficiency and Total Factor Productivity (TFP) of lowland paddy rice farmers in Kwara State of Nigeria.
\end{abstract}

Research Methodology: The study made use of cross-sectional data collected from 200 active farmers during the 2016 cropping season via Multi-stage sampling technique. Instrument used to elicit information from the active farmers was structured questionnaire complemented with interview schedule and the collected data were analyzed using descriptive and inferential statistics.

Findings: The results proved that majority of the farmers were not smart farmers which is responsible for negative TFP in most of the Decision making units (DMUs) as evident from poor robust increase in output index. However, the study inferred that there remained more untapped potentials in paddy rice production in the studied area.

Limitations: The scope of the research is limited to lowland rice farmers in Kwara State of Nigeria.

Originality/Value: Therefore, it was recommended that Government and non-governmental organisations should formulate supportive policies targeting sustainability of rice production viz. proper allocation of farm resources and also welfare improvement of the resource poor farmers for cultivating rice crops in the studied area.

Keywords: TFP, Efficiency, Lowland, Paddy rice, Nigeria

\section{INTRODUCTION}

Rice is one of the most important food commodities in West Africa. Studies conducted in Nigeria reported that rice constitutes over $20 \%$ of total food expenditure among the urban and rural households (SAHEL, 2015). Statistics have shown that annual rice production in Nigeria has increased from 5.5 million tonnes in 2015 to 5.8 million tonnes in 2017. This increase is according to a result of the Central Bank of Nigeria (CBN); Anchor borrowers programme which has a total of 12 million rice producers and four million hectares of Fadama (mash soil submerged in water) rice land (Leadership Newspaper, 2017) . RIFAN as cited by Punch
Newspaper (2017) reported that in 2015, Nigerians spent not less than 1 billion naira on rice consumption, adding that while spending had drastically reduced, consumption had increased because of increased local production of the commodity. The present consumption rate of 7.9 million tonnes indicates a mismatch between supply and demand to the tune of 2.1 million tonnes. However, the programme since inception had created economic linkage between small-holder farmers and reputed large

\footnotetext{
${ }^{1 *}$ Department of Agricultural Economics, FUT, P.M.B. 65, Minna, Nigeria.sadiqsanusi30@gmail.com

${ }^{2}$ Department of Agricultural Economics, FUT, Minna, Nigeria
} 
scale processors, thereby increasing agricultural outputs and significantly improving capacity utilization of processors. However, the crux is that the output increase is due to hectare increase rather than productivity increase which in the long-run is not sustainable due to high competition between urbanization growth and farm sector for land. Daily Trust Newspaper (2016) reported that the federal government of Nigeria (FGN) has promised to assist Kwara state in its rice expansion programme to boost food sufficiency in the country. But the issue is that paddy production in the state is dominated by smallholder farmers, who use poor agronomic practices, thus, making the cultivation and production of this highly prized and very important food crop dwindling. One way these resource-poor farmers, who contribute more than $90 \%$ of agricultural output in Nigeria (FMAWR, 2008), can enhance production and ensure sustainability within the limit of existing resource base will be through more efficient usage of resources. Low resource productivity has been attributed to the significant difference between the actual and potential yields (FMARD, 2001). Therefore, in order not to be caught in the web as production will be complemented by adequate provision of farm implements and inputs as promised by FGN, there is need to overhaul the rice production at the micro level so that lapses affecting productivity can be identified for immediate intervention. This becomes imperative in order to make FGN intervention in rice production in the state successful. The total factor productivity (TFP), as a measure of overall productivity, has gained recognition not only for its theoretical correctness, but also for its peculiarity among policy makers and economic analysts. The growth of TFP provides the society with an opportunity to increase the welfare of the society. Productivity growth defined as the efficiency with which inputs are transformed into output in the production is an aspect in the study area and even the country in general that has received little or no empirical research exploration. It is against this background that the study ought to verify the dynamism of total factor productivity in lowland rice production because productivity is considered as a contributing factor to the economic growth of a nation. The specific objectives were:-

i. To describe the socio-economic profile of the respondents;

ii. To estimate profitability of lowland paddy rice production in the studied area;

iii. To evaluate income distribution among the respondents;

iv. To determine technical, cost, allocative efficiencies and TFP of the respondents in the studied area;

v. To identify the factors that influenced efficiencies and TFP of paddy rice farmers in the studied area; and,

vi. To identify the factors hindering rice production in the studied area.

\section{RESEARCH METHODOLOGY}

The coordinates of Kwara state in Nigeria are between longitudes $4^{0} 20^{\prime}$ and $4^{0} 25^{\prime}$ East of the Greenwich meridianwich and latitudes $8^{\circ} 30^{\circ}$ and $8^{0} 50^{\prime}$ North of the equator. The population of the state is about 2.3 million, approximately $1.69 \%$ of the total population of the country (NPC, 2006) having relied upon immigration for population growth and development. The landmass of the state is approximately 36,825 square kilometres with varying physical features like hills, lowland, rivers etc., and the vegetation is derived savannah with two main distinct seasons; the wet and dry seasons. The mean annual precipitation and monthly temperature ranges between $1000-1500 \mathrm{~mm}$ and $25^{\circ} \mathrm{C}-34^{\circ} \mathrm{C}$ respectively (NBS, 2010). The major occupation of the inhabitants is agricultural activities complemented with trade, artisanal, ayurvedic medicine etc. The study utilized cross sectional data collected from 200 farmers' via multi-stage sampling design. The stage-wise sampling procedure is as follows: The purposive selection 
of agricultural zone B viz. Edu and Patigi Local Government Areas due to their comparative advantage in rice production; random selection of five (5) villages from each of the selected LGAs; and, random selection of twenty (20) farmers from each of the selected villages, thus, given a total sample size of 200 active rice farmers. The instrument for data collection was structured questionnaire complemented with interview schedule. For reliability test of the questionnaire, the questionnaire was pretested in a pilot survey made up of 25 farmers from the sampling population and the estimated Cronbach Alpha was 0.723, indicating high reliability and consistency of the questionnaire. With the aid of block extension agents, ex-post data of 2016 cropping season were collected in the year 2017. The collected data were analyzed using descriptive and inferential statistics. Objective I and part of VI were achieved using descriptive; objective II was achieved using cost concepts and income measures developed by Dr. Sen's committee report (1979); objective III was achieved using Gini coefficient in conjunction with Lorenz curve; objective IV was achieved using non-parametric model: DEA for technical, cost, allocative efficiencies measurement and Tornqvist TFP index for TFP; objective $\mathrm{V}$ was achieved using Tobit regression model (Generalized linear model); and, Kendal coefficient of concordance (KCC), Friedman's $\mathrm{Chi}^{2}$ statistic and Exploratory factor analysis were used to achieve part of objective VI.

\section{Empirical model}

\section{Gini Coefficient}

It is a statistical measure of dispersion developed by an Italian statistician named Corrado Gini and published in his paper "Variability and Mutability" (Italian: Variabilitae mutabilita). The Gini index is defined as a ratio of the areas on the Lorenz curve. The formula is specified as follows:

$\mathbf{G}=\mathrm{A} / 0.5=2 \mathrm{~A}=1-2 \mathrm{~B}$

\section{Cost concepts and Income measures}

Cost concepts and income measures are widely used because of their relevance in decisionmaking process. This means that these costs serve as a basis to expand the size of the farm, to buy the requisite capital assets in the long run and the requisite inputs in the short run. The study adopted the cost concepts developed by Subba et al., (2016) and Dr. Sen's committee report (1979), and are specified below:

\section{Cost Concepts}

Costs related to paddy rice production are split up into various cost concepts such as $A_{1}, A_{2}, B$, $\mathrm{C}$ and $\mathrm{D}$

Opportunity cost: costs of self-owned and selfemployed resource i.e imputed/implicit cost

Accounting cost: costs for purchasing and hiring of inputs and input services i.e Paid out costs/cash costs/ nominal/money cost

Economic cost: Opportunity cost + Accounting cost

Cost $A_{1}$ : The following items are included in $\operatorname{Cost} A_{1}$

Wages of hired labour

Charges of hired machinery

Market rate of fertilizers

Market rate of seeds

Market value of biocides

Land revenue, cess and other tax

Depreciation of farm implements

Interest on working capital

Miscellaneous expenses

$\operatorname{Cost} A_{2}: \operatorname{Cost} A_{1}+$ rent paid for leased in land

Cost B: Cost $A_{1}$ or $A_{2}+$ interest on fixed capital excluding land + rental value of owned land

Cost C: Cost B + imputed value of family labour

Cost D: Cost $\mathrm{C}+10 \%$ of Cost $\mathrm{C}$ as management cost (Meena et al., 2016) 


\section{Income Measures}

These are the returns over different cost concepts. Different income measures are derived using the cost concepts. These measures are given below:

Farm business income $=$ Gross income - Cost $\mathrm{A}_{1}$ or $\mathrm{A}_{2}$

Family labour income $=$ Gross income - Cost B (3)

Net income $=$ Gross income - Cost D (4)

Farm investment income $=$ Farm business income - Imputed value of family labour Imputed management cost (or) Net income + Imputed rental value of owned land

Return on Naira invested $(\mathrm{ROI})=\frac{\text { Gross margin }}{\text { Total variable cost }}$.

Rate of return on capital invested $(\mathrm{RORCI})=\frac{\text { Net farm income }}{\text { Total cost }}$

\section{Data envelopment analysis}

The DEA is a non-parametric data analytical technique whose domain of inquiry is a set of entities, commonly called decision-making units (DMUs), which receive multiple inputs and produce multiple outputs [Hedari et al.(2012) as cited by Khoshnevisan et al.(2013)]. The CCR model which was built on the assumption of constant returns to scale (CRS) was suggested by Charnes, Cooper and Rhodes (Charnes et al., 1978) and is also called global efficiency model, while BCC model which was built on variable returns to scale (VRS) was introduced by Banker, Charnes and Cooper (Banker et al., 1984) and is called the local efficiency model.

Technical efficiency is defined as the ratio of observed output to the maximum potential output. Thus, technical efficiency can be expressed as:

$$
\mathrm{TE}_{\mathrm{i}}=\frac{Q}{Q_{*}}
$$

The cost efficiency of an individual farm is defined in terms of the ratio of minimum cost to the corresponding observed cost given the available technology. That is:

$$
\mathrm{CE}_{\mathrm{i}}=\frac{\mathrm{w}^{\prime} \mathrm{X} *}{\mathrm{w}^{\prime} \mathrm{x}}
$$

Allocative efficiency is given below:

$$
\mathrm{AE}=\frac{C E}{T E}
$$

I he output is paddy rice; while the inputs were family labour, hired labour, seeds, NPK fertilizer, Urea fertilizer, herbicides, tractor machinery, diesel fuel, depreciation on capital item and farm size.

\section{Total factor productivity index}

The productivity of a single-output single-input firm is almost always defined as the output-input ratio. O'Donnell (2008) generalizes this idea to the multiple-output multiple-input case by formally defining the Total Fctor Productivity (TFP) of a firm to be the ratio of an aggregate output to an aggregate input. Let $x_{i t}=\left(x_{1 i t}\right.$ $\left., \ldots \ldots \ldots, x_{k i}\right)^{\prime}$ 'and $q_{i t}=\left(q_{1 i t}, \ldots \ldots \ldots, q_{k i}\right)^{\prime}$ 'denote the input and output quantity vectors of firm $i$ in period $t$. Then the TFP of the firm is:

$$
T F P=\frac{Q i t}{X i t} .
$$

(Total Factor Productivity)

Where, $Q_{i t}=Q\left(q_{i l}\right)$ is an aggregate output, $X_{i t}$ $=X\left(x_{i}\right)$ is an aggregate input, and $Q($.) and $X()$. are nonnegative, non-decreasing and linearly homogeneous aggregator functions. The associated index number that measures the TFP of $i^{\text {th }} \mathrm{f}$ ir min period $t$ relative to the TFP of firm $h$ in period $s$ is:

$$
T F P_{\text {hs, it }}=\frac{T F P i t}{T F P h s}=\frac{Q i t / X i t}{Q h s / X h s}=\frac{Q h s, i t}{Q h s, i t}
$$

(11) (TFP index)

Where $Q_{h s, i t}=$ is an output quantity index and $X_{h s, i t}=$, is an input quantity index. 


\section{Tobit model}

The original Tobit model developed by James Tobin a Nobel laureate economist (Tobin, 1958) was adopted for this study and it is given below:

$Y_{i}^{*}=\alpha+X \beta+\varepsilon i$

Where $\mathrm{Y}_{i}^{*}$ is a latent variable. Now

$$
\begin{aligned}
& Y_{i}=0 \text { if } Y_{i}^{*} \leq 0 \\
& \quad=Y_{i}^{*} \text { if } Y_{i}^{*}>0 \\
& Y_{i}^{*}=\alpha+X_{1} \beta_{1}+X_{2} \beta_{2}+X_{3} \beta_{3}+X_{4} \beta_{4}+X_{5} \beta_{5}+ \\
& X_{8} \beta_{6}+X_{7} \beta_{7}+X_{8} \beta_{8}+X_{9} \beta_{9}+X_{10} \beta_{10}+X_{11} \beta_{11}+ \\
& X_{12} \beta_{12}+\varepsilon_{i}
\end{aligned}
$$

Where:

$\mathrm{Y}_{i}^{*}=$ censored latent observation (Technical, Cost, Allocative efficiencies or TFP index) for $\mathrm{i}^{\text {th }}$ farmer

$\mathrm{X}_{1}=$ Age $($ Year $(\mathrm{s}))$

$\mathrm{X}_{2}=$ Marital status (Married $=1$, Otherwise $=0$ )

$\mathrm{X}_{3}=$ Educational level (Educated $=1$, Otherwise $=0$ )

$\mathrm{X}_{4}=$ Household size $($ Number(s))

$\mathrm{X}_{5}=$ Farming Experience (Year(s))

$\mathrm{X}_{6}=$ Farm size $($ Hectare $(\mathrm{s}))$

$\mathrm{X}_{7}=$ Land ownership $($ Yes $=1$, Otherwise $=0)$

$\mathrm{X}_{8}=$ Seed variety (Improved variety $=1$, Otherwise $=0$ )

$\mathrm{X}_{9}=$ Non-farm activity $($ Yes $=1$, Otherwise $=0$ )

$\mathrm{X}_{10}=$ Extension contact $($ Yes $=1$, Otherwise $=$ 0)

$\mathrm{X}_{11}=$ Access to credit $($ Yes $=1$, Otherwise $=0$ )

$\mathrm{X}_{12}=$ Security $($ Yes $=1$, Otherwise $=0)$

$\alpha=$ Intercept

$\mathrm{B}_{1-\mathrm{n}}=$ Coefficients

$\varepsilon_{i}=$ Error term

\section{Kendall's Coefficient of Concordance (W)}

Kendall's coefficient of concordance $(W)$ proposed by Maurice G. Kendall and Bernard Babington-Smith is a measure of agreement among several ' $m$ ' variables that are assessing a set of ' $n$ ' objects of interest. In social sciences, the variables are often people, called judges or respondents, assessing different subjects or situations. Kendall's coefficient of concordance $(W)$ uses the $\chi 2$ statistic for testing. If the test statistic $W$ is 1 , then all the survey respondents have been unanimous and each respondent has assigned the same order to the list of subjects or situations. If $W$ is 0 , then there is no overall trend of agreement among the respondents and their responses may be regarded as essentially random. Intermediate values of $W$ indicate a greater or lesser degree of agreement among the various respondents. Following Sadiq et al.(2017) the Kendall's coefficient of concordance developed by Kendall and Smith (1939) and Wallis (1939) is given below:

$$
W=\frac{12 S}{k 2 n(n 2-1)-k T}
$$

Where;

$\mathrm{S}=$ Sum over all subjects

$\mathrm{k}=$ Number of respondents ranking the attributes or objects

$\mathrm{n}=$ Number of attributes or objects that is evaluated by respondents

$\mathrm{T}=$ Tie-correction factor

$T=\sum\left(t_{k}^{3}-t_{k}\right)$

' $t_{k}$ ' is the number of tied ranks in each $(k)$ of $\mathrm{g}$ groups of ties. The sum is computed over all groups of ties found in all $\mathrm{m}$ variables of the data table. $T$ is 0 when there are no tied values.

The $\mathrm{Chi}^{2}\left(\chi^{2}\right)$ statistic is given as follow:

$\chi^{2}=k(n-1) W$

Where;

$\mathrm{k}=$ Number of respondents

$\mathrm{n}=$ Number of objects or attributes being ranked

$W=$ Kendall's coefficient of concordance (KCC) 


\section{Friedman's Chi-square Statistic:}

The Friedman's Chi-square statistic proposed by Friedman (1937) was developed primarily to test the hypothesis that the ratings assigned to subjects under investigation come from the same statistical population. This is an indirect way of evaluating the extent of agreement among raters. Due to its close mathematical relationship with Kendall's coefficient of concordance $(W)$ it is used in studies of interjudge reliability. The Friedman's Chi-square statistic is given below:

$\chi_{r}^{2}=k(n-1) W$

\section{Where;}

$\chi_{\mathrm{r}}^{2}=$ Friedman's chi ${ }^{2}$ statistic $; \mathrm{k}=$ Number of respondents $; \mathrm{n}=$ Number of objects or attributes being ranked ; $W=$ Kendall's coefficient of concordance $(\mathrm{KCC})$

\section{RESULTS AND DISCUSSION}

\section{Socio-Economic Profile of Lowland Paddy Rice Farmers in the Studied Area}

Presented in Table 01 are the socio-economic profiles of lowland paddy rice farmers in the studied area. A perusal of the table showed an active and productive farming population as evident from the mean age of 47.35 years and a marginal standard deviation of 11.58. This implies that majority of the farmers in the studied area have their age around the mean age recommended to be economically active, hence they possess the ability to earn a remunerative revenue from rice farming. Farmers within the youthful age are presumed to commit more energy into production activities as well as possessing the potentials to cope with challenges inherent with the modernized/mechanized farming system. In addition, age of a farmer is very crucial in determining the quality of the physical activities committed to farming; farmers' age to a large extent has an important bearing upon effectiveness in the performance of various management and operational duties of lowland paddy rice production. The enterprise in the studied area was observed to be mainly men affairs and this is attributed to the drudgery involved and to a certain extent towards cultural and religious barriers which limit women participation to non-farm activities. In addendum women are not entitled to be in possession of land because custom classifies women to be subjects. The results further show that majority of the farmers in the studied area were married $(87.5 \%)$ with conglomerated left over of $12.5 \%$ been single, widowed/widower and divorced. The implication is that married farmers would have the twin advantage of social and economic power, thus a plus to their income stream base in rice farming. The results showed a literate farming population with the majority $(69.5 \%)$ of the farmers possessing one form of formal education or the other. The implication is that this farming population would be receptive to any effective innovation aimed at increasing their productivity which in turn will augment their income base from rice farming. Indeed, a farmer who is able to read and write in formal languages has the facilities to interact with other actors in the agricultural sector and thus gains new experiences in order to achieve the production objectives. Also, it will be easier for this farming population to adopt innovation and modern agricultural practices which require basic educational levels in order to increase their efficiency and productivity. In addition, it would afford the farmers the opportunity to weigh and compare the various innovation introduced in order to make a rational decision in allocation of farm resources. It was observed that majority of the farmers had a large household size as indicated by the mean household size of 12 persons and standard deviation value of 7.9. The pros of large household size if majority are able bodied is that the farmer would have access to free labour which imply reduction in labour expenses incurred in farming operation since there will be little or no need for hired labour and also have increased income stream; while the cons if the household is dominated by weaker people means drain on farmer's per capita income due to excessive expenditure on food consumption and family up keepings, thus affecting his/her standard of living. 
Table 01: Socio-economic profile of the farmers

\begin{tabular}{|c|c|c|c|c|}
\hline Variables & Frequency & Percentage & $\mathrm{X} \pm \mathrm{SD}$ & $\chi^{2}$ test statistic \\
\hline \multicolumn{5}{|l|}{ Age } \\
\hline$\leq 29$ & 18 & 9.0 & & \multirow{6}{*}{$35.15(0.000)$} \\
\hline $30-39$ & 35 & 17.5 & & \\
\hline $40-49$ & 66 & 33.0 & & \\
\hline $50-59$ & 51 & 25.5 & & \\
\hline$\geq 60$ & 30 & 15.0 & & \\
\hline Total & 200 & 100 & 11.58 & \\
\hline \multicolumn{5}{|l|}{ Gender } \\
\hline Male & 200 & 100 & & \multirow{3}{*}{-} \\
\hline Female & - & - & & \\
\hline Total & 200 & 100 & & \\
\hline \multicolumn{5}{|l|}{ Marital status } \\
\hline Married & 175 & 87.5 & & \multirow{5}{*}{$417.88(0.000)$} \\
\hline Single & 12 & 6.0 & & \\
\hline Widower & 11 & 5.5 & & \\
\hline Divorce & 2 & 1.0 & & \\
\hline Total & 200 & 100 & & \\
\hline \multicolumn{5}{|c|}{ Educational level } \\
\hline Informal & 61 & 30.5 & & \multirow{6}{*}{$22.25(0.000)$} \\
\hline Quranic & 43 & 21.5 & & \\
\hline Primary & 34 & 17.0 & & \\
\hline Secondary & 42 & 21.0 & & \\
\hline Tertiary & 20 & 10.0 & & \\
\hline Total & 200 & 100 & & \\
\hline \multicolumn{5}{|l|}{ Household size } \\
\hline$\leq 3$ & 19 & 9.5 & & \multirow{5}{*}{$112.08(0.000)$} \\
\hline $4-6$ & 25 & 12.5 & & \\
\hline $7-9$ & 43 & 21.5 & & \\
\hline$\geq 10$ & 113 & 56.5 & & \\
\hline Total & 200 & 100 & 7.9 & \\
\hline \multicolumn{5}{|c|}{ Farming experience } \\
\hline$\leq 3$ & 15 & 7.5 & & \multirow{5}{*}{$272.12(0.000)$} \\
\hline $4-6$ & 18 & 9.0 & & \\
\hline $7-9$ & 16 & 8.0 & & \\
\hline$\geq 10$ & 151 & 75.5 & & \\
\hline Total & 200 & 100 & 9.6 & \\
\hline \multicolumn{5}{|l|}{ Farm size } \\
\hline Marginal $(\leq 1)$ & 69 & 34.5 & & \multirow{5}{*}{$88.40(0.000)$} \\
\hline Small (1-2) & 93 & 46.5 & & \\
\hline Medium (3-4) & 31 & 15.5 & & \\
\hline Large $(\geq 5)$ & 7 & 3.5 & & \\
\hline Total & 200 & 100 & 1.31 & \\
\hline \multicolumn{5}{|c|}{ Land acquisition } \\
\hline Inheritance & 182 & 91.0 & & \multirow{3}{*}{$134.48(0.000)$} \\
\hline Borrowed & 18 & 9.0 & & \\
\hline Total & 200 & 100 & & \\
\hline
\end{tabular}




\begin{tabular}{|c|c|c|c|c|}
\hline Variables & Frequency & Percentage & $\mathrm{X} \pm \mathrm{SD}$ & $\chi^{2}$ test statistic \\
\hline \multicolumn{5}{|l|}{ Seed variety } \\
\hline Local & 196 & 98.0 & & \multirow{3}{*}{$184.32(0.000)$} \\
\hline Improved \& Local & 4 & 2.0 & & \\
\hline Total & 200 & 100 & & \\
\hline \multicolumn{5}{|l|}{ Extension contact } \\
\hline Yes & 23 & 11.5 & & \multirow{3}{*}{$118.58(0.000)$} \\
\hline No & 177 & 88.5 & & \\
\hline Total & 200 & 100 & & \\
\hline \multicolumn{5}{|c|}{ Co-operative membership } \\
\hline Yes & 123 & 61.5 & & \multirow{3}{*}{$10.58(0.000)$} \\
\hline No & 77 & 38.5 & & \\
\hline Total & 200 & 100 & & \\
\hline \multicolumn{5}{|l|}{ Access to credit } \\
\hline Yes & 123 & 61.5 & & \multirow{3}{*}{$10.58(0.000)$} \\
\hline No & 77 & 38.5 & & \\
\hline Total & 200 & 100 & & \\
\hline \multicolumn{5}{|l|}{ Non-farm activities } \\
\hline Yes & 184 & 92.0 & & \multirow{3}{*}{$141.12(0.000)$} \\
\hline No & 16 & 8.0 & & \\
\hline Total & 200 & 100 & & \\
\hline \multicolumn{5}{|l|}{ Security } \\
\hline Yes & 13 & 6.5 & & \multirow{3}{*}{$151.38(0.000)$} \\
\hline No & 187 & 93.5 & & \\
\hline Total & 200 & 100 & & \\
\hline
\end{tabular}

Source: Field survey, 2017

However, FAO recommended household size of less than seven for a typical agrarian setting in Africa is the best for a better livelihood status in order not to make the farmers prone to marketed surplus. Majority of the farmers were observed to have adequate years of experience in rice farming in the studied area as evident from mean farming experience of 15.94 years with standard deviation value of 9.63 . The implication is that efficiency level in rice production is expected to be high as experienced farmers will be better equipped with the nitty-gritty of production techniques, climatic change coping strategies and market outlooks that would pave way for a more efficient and profitable rice enterprise in the studied area. Also, adequate experience in farming is an important determinant of profitability because it will allow farmers to adjust to changing economic conditions and adopt the most efficient cultural practices. The results showed that majority of the farmers operated on small-scale $(46.5 \%)$, while 34.5 ,
15.5 and $3.5 \%$ were marginal, medium and large scale farmers respectively. The mean farm size of 1.7 hectare further buttresses the dominancy of small-scale farmers in the studied area. A cumulative of $81 \%$ implies that the farmers were peasant/subsistence farmers and need to be encouraged in order to attain food security status at micro and macro levels. However, the reason why most were peasant farmers may be due to the fact that they depend on family as a source of capital and labour. Majority of the farmers used local seed varieties and had no extension contact during the study period. Extension contact is considered as an indispensable element in the adoption of new technologies because it links farmers to information about the existence of a new technology and the associated; improves and reinforces the decision to adopt a technology. Therefore, scarcity of extension contact or its disappearance will lead to the abandon of the different technologies. 
Furthermore, it was observed that most of the farmers had access to credit and belong to a social organization. Access to credit and participation in a social organization will avail the farmers with the opportunity of timely input purchase which is very vital to the going concern of an enterprise. In addition, participation in a social organization would make farmers to benefit bulk discounts from input purchase, output/product marketing bargaining power and other pecuniary advantages. The presence of a group will enable the locality to have contact with support structures. In order to ensure efficient use of scarce resources, agricultural extension programs preferred farmers' associations assuming that messages will spread quickly through the group to other farmers. In addition, social organizations/ groups encourage their members to change their attitudes. Also observed is that majority of the farmers acquired their lands through inheritance. The implication would be further fragmentation of farm holding due to pressure by each adult member of the family to have his share of the holding thereby discouraging commercial production. The results showed that majority of the farmers engaged in non-farm activities. The implication of this result is that the seasonal nature of farming made farmers in the studied area to engage themselves in nonfarm activities in order to keep the body and the soul together. In addition, participation in other non-farm activities would help to increase their income streams. The results also showed that there is not much security threat to farming in the studied area. The implication is that farming activities can only be carried out in a peaceful and safe environment because security is very vital for human existence. The results of the $\mathrm{Chi}^{2}\left(\chi^{2}\right)$ test statistics for all the socio-economic characteristics considered were significant at $1 \%$ probability level, indicating differences in the distributional proportion of each variables.

\section{Costs and Returns Structure of Lowland Rice Production per hectare}

Shown in Table 02a-02c is the cost of cultivation and return structure of lowland paddy rice production per hectare. A perusal of the table showed the economic and accounting costs of cultivation to be $\$ 58300.62$ and \#35736.56respectively. The decomposition analysis showed the share contribution of total economic variable cost (TEVC) and total economic fixed cost (TEFC) in economic cost of cultivation to be 68.07 and $31.93 \%$ respectively; while the share contribution of total accounting variable cost (TAVC) and total accounting fixed cost (TAFC) in accounting cost of cultivation were 68.34 and $31.66 \%$ respectively. For the return structure, the economic and accounting revenue per hectare were $\$ 65614.22$ and $\$ 41414.87$ respectively. Furthermore, the profitability decomposition results showed the economic gross margin cum net farm income to be $\$ 25929.67$ and $\$ 7313.60$ respectively, while the accounting gross margin cum net farm income were $\$ 16994.32$ and $\$ 5678.31$ respectively. Therefore, at farm level, it can be concluded that lowland paddy rice production was a profitable venture in the studied area. The economic and accounting ROI were 0.65 and 0.70 respectively, implying that for every N1 invested in the enterprise, an economic and accounting profit of 65 and 70kobos respectively, were gained. This profit margin should stimulate financing from the lending institutions, because if lowland paddy rice farmers in the studied area are funded with $\$ 50000.00$ at an interest rate of $8 \%$, the farmer will return the principal of $\$ 50000.00$, interest of $\$ 4000.00$ and retain N11614.22 as profit. The implication of this result is that there is a considerable level of profit in lowland paddy rice farming in the studied area. The rate of return per unit of capital invested (RORCI) indicates what is earned by the business through capital outlay. The results revealed that the economic and accounting RORCI of 13 and $16 \%$ respectively, were greater than the prevailing bank lending rate of $8 \%$, thus, further justifying the profitability of lowland paddy rice farming in the studied area. Therefore, if a farmer takes a loan from the bank to finance lowland paddy rice farming, in respect of economic and accounting status he will be 5 and $8 \%$ respectively, better off on every one naira spent after 
Table 02a: Costs and returns estimates of paddy rice production per hectare

\begin{tabular}{|c|c|c|c|}
\hline Items & Quantity & Unit price ( & 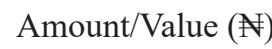 \\
\hline \multicolumn{4}{|l|}{ Variable costs } \\
\hline Family labour & 56.32 manhour & 200 & 11264.00 \\
\hline Hired labour & 20.16 manhour & 200 & 4032.00 \\
\hline Seeds & $27.42 \mathrm{~kg}$ & 133 & 3646.85 \\
\hline NPK fertilizer & $19.36 \mathrm{~kg}$ & 160 & 3097.60 \\
\hline Urea & $18.85 \mathrm{~kg}$ & 170 & 3204.50 \\
\hline Herbicides & 2.1 litre & 1600 & 3360.00 \\
\hline Tractor & 0.33 tractor hour & 7000 & 2310.00 \\
\hline Diesel fuel & 29.8 litre & 160 & 4769.60 \\
\hline $\begin{array}{l}\text { Imputed value of interest on working } \\
\text { capital }\end{array}$ & $8 \%$ of 50000 & - & 4000.00 \\
\hline Total variable cost & & & 39684.55 \\
\hline \multicolumn{4}{|l|}{ Fixed costs } \\
\hline Depreciation on capital & $20 \%$ & & 11316.01 \\
\hline Imputed rental value of owned land & - & & 2000.00 \\
\hline Imputed managerial cost & $10 \%$ of Total cost & & 5300.06 \\
\hline Total fixed cost & & & 18616.07 \\
\hline Total cost & & & 58300.62 \\
\hline \multicolumn{4}{|l|}{ Returns } \\
\hline Quantity sold & $311.39 \mathrm{~kg}$ & 133 & 41414.87 \\
\hline Quantity consumed & $150.17 \mathrm{~kg}$ & 133 & 19972.61 \\
\hline Quantity gifted & $31.78 \mathrm{~kg}$ & 133 & 4226.74 \\
\hline Total output & $493.34 \mathrm{~kg}$ & 133 & 65614.22 \\
\hline
\end{tabular}

Source: Field survey, 2017

Table 02b: Cost concepts

\begin{tabular}{lc}
\hline \multicolumn{1}{c}{ Items } & Amount $(\mathrm{N})$ \\
\hline Total variable opportunity cost & 15264.00 \\
Total fixed opportunity cost & 7300.06 \\
Total opportunity cost & 22564.06 \\
Total variable accounting cost & 24420.55 \\
Total fixed accounting cost & 11316.01 \\
Total accounting cost & 35736.56 \\
Total variable economic cost & 39684.55 \\
Total fixed economic cost & 18616.07 \\
Total economic cost & 58300.62 \\
Cost A & 39736.56 \\
Cost B & 41736.56 \\
Cost C & 53000.56 \\
Cost D & 58300.62 \\
\hline
\end{tabular}

Source: Authors' computation 
Table 02c: Income measures

\begin{tabular}{lc}
\hline \multicolumn{1}{c}{ Items } & Value (N) \\
\hline Accounting gross margin & 16994.32 \\
Accounting net farm income & 5678.31 \\
Accounting return on naira invested (AROI) & 0.70 \\
Accounting rate of return on per capital invested (ARORCI) & 0.16 \\
Account cost of production & 114.77 \\
Farm business income & 25877.66 \\
Family labour income & 23877.66 \\
Economic gross margin & 25929.67 \\
Economic net farm income & 7313.60 \\
Farm investment income & 9313.6 \\
Economic return on naira invested (EROI) & 0.65 \\
Economic rate of return on per capital invested (ERORCI) & 0.13 \\
Economic cost of production & 118.18 \\
\hline
\end{tabular}

Source: Authors' computation, 2017

Income Distribution of the Farmers in the Studied Area

The estimated Gini coefficient value of 0.385 implies a moderate equality in income distribution among rice farmers in the studied area (Table 03). This distribution is visible from the diagrammatic Lorenz curve which is fairly farther from the line of equality (Figure $01)$. The moderate equality in the distribution of the income among the farmers is due to inverse relationship between farm income and non-farm income; while farm income decreases inequality, non-farm and off-farm income increases inequality. Therefore, since income from non-farm and off-farm incomes increase inequality, the study call for removal of barriers hindering opportunities in rice farming so that it can have an equalizing effect on income distribution. However, this requires adequate provision of education and accessible credit schemes, coupled with provision of physical infrastructures that will create more economic opportunities for the farmers in the studied area.

Table 03: Annual Income distribution of the farmers

\begin{tabular}{lc}
\hline \multicolumn{1}{c}{ Item } & Coefficient \\
\hline Gini coefficient & 0.3846 \\
Estimate of population value & 0.3865 \\
\hline
\end{tabular}

Source: Field survey, 2017

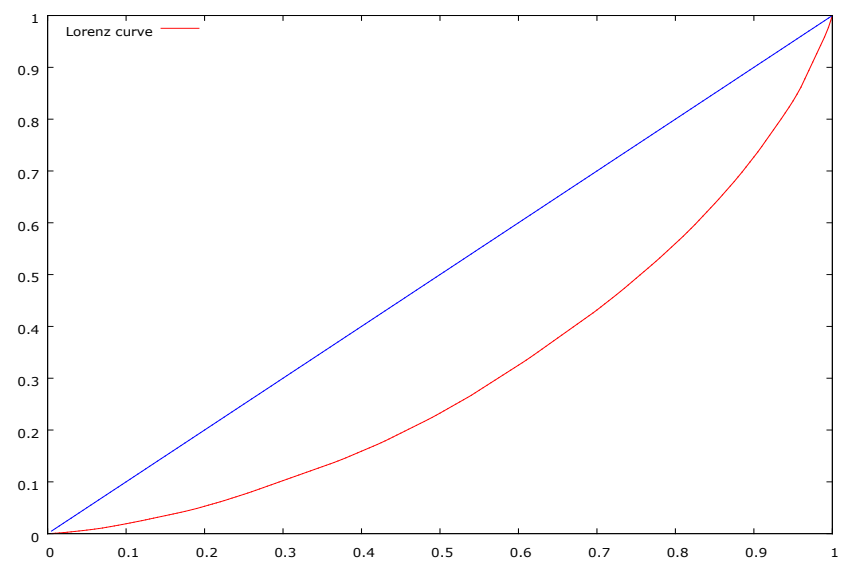

Figure 01: Inocome distribution of rice farmers in the study area 
Measuring Technical, Cost and Allocative efficiencies of Rice Farmers in the Studied Area

Presented in Table 04 are the deciles distribution scores for technical (TE), cost (CE) and allocative (AE) efficiencies of lowland paddy rice farmers in the studied area. A perusal of the table showed that the deciles range for TE, CE and $\mathrm{AE}$ were 0.08 to 1.00 with a mean score of $0.592 ; 0.029$ to 0.100 with a mean score of 0.246 ; and, 0.10 to 1.00 with a mean score of 0.423 , respectively. The implication of the mean statistic is that on the average approximately $40.8 \%$ of paddy rice output is lost as a result of technical inefficiency; $75.40 \%$ of the cost incurred on rice production was wasted as a result of cost inefficiency; and, $57.70 \%$ of the scare resources used in rice production were not efficiently allocated. Therefore, the inference of the mean statistics with respect to TE, CE and $\mathrm{AE}$ in the short-run, implies that there is scope to increase paddy rice production by $40.80 \%$ by adopting the techniques practised by the smart farmers; the chance to reducing incurred costs by $75.40 \%$ by adopting the smart farmers cost saving strategies; and the tendency of increasing allocative efficiency by $57.70 \%$ by emulating the smart farmers allocation pattern for scarce resources. From the results it was observed that $87,99.5$ and $99.5 \%$ of the respondents were not smart farmers with respect to TE, CE and $\mathrm{AE}$ respectively, because their efficiency scores were below 1, implying that they operated below the frontier surface.

\section{TFP Levels of Rice Producers' in the Studied Area}

The increase in input use to a certain extent allows the farm sector to move along the production surface. The balanced use of inputs is expected to induce an upward shift in the production function to the extent that a technological change is embodied in them. The TFP measures the extent of increase in the total output which is not accounted for by increases in the total inputs. The estimated input, output and TFP index of rice production in the studied area as at 2016 cropping season are shown in Table 05.

Table 04: Deciles distribution of Technical, Cost and Allocative efficiency scores

\begin{tabular}{cccc}
\hline Score & TE & CE & AE \\
\hline$\leq 0.09$ & $2(1.0)$ & $27(13.5)$ & - \\
$0.10-0.19$ & $10(5.0)$ & $54(27.0)$ & $7(3.5)$ \\
$0.20-0.29$ & $16(8.0)$ & $63(31.5)$ & $28(14.0)$ \\
$0.30-0.39$ & $28(14.0)$ & $31(15.5)$ & $55(27.5)$ \\
$0.40-0.49$ & $23(11.5)$ & $16(8.0)$ & $51(25.5)$ \\
$0.50-0.59$ & $27(13.5)$ & $7(3.5)$ & $44(22.0)$ \\
$0.60-0.69$ & $24(12.0)$ & $1(0.5)$ & $12(6.0)$ \\
$0.70-0.79$ & $23(11.5)$ & - & $1(0.5)$ \\
$0.80-0.89$ & $10(5.0)$ & - & $1(0.5)$ \\
$0.90-0.99$ & $11(5.5)$ & - & - \\
1.00 & $26(13.0)$ & $1(0.5)$ & $1(0.5)$ \\
Total & 200 & 200 & 200 \\
Mean & 0.592 & 0.246 & 0.423 \\
SD & 0.261 & 0.134 & 0.132 \\
CV & 0.441 & 0.543 & 0.313 \\
Minimum & 0.080 & 0.029 & 0.102 \\
Maximum & 1.000 & 1.000 & 1.000 \\
Skewness & 0.105 & 1.302 & 0.460 \\
Kurtosis & -1.051 & 4.216 & 1.240 \\
IQ range & 0.404 & 0.162 & 0.187
\end{tabular}


Table 05: Estimated input, output and TFP index of rice production in the studied area

\begin{tabular}{cccccccc}
\hline Farm & Output & Input & TFP & Farm & Output & Input & TFP \\
\hline DMU11 & 3.5862 & 2.7146 & 1.3211 & DMU82 & 1.7931 & 1.7815 & 1.0065 \\
DMU12 & 1.9770 & 1.8235 & 1.0842 & DMU 86 & 1.1149 & 1.1112 & 1.0034 \\
DMU21 & 1.2874 & 1.1635 & 1.1064 & DMU87 & 1.7241 & 1.4243 & 1.2105 \\
DMU22 & 1.5632 & 1.4741 & 1.0605 & DMU89 & 2.0115 & 1.4854 & 1.3542 \\
DMU26 & 0.5747 & 0.4066 & 1.4135 & DMU96 & 0.8644 & 0.6286 & 1.3750 \\
DMU31 & 2.8736 & 2.3913 & 1.2017 & DMU99 & 1.7241 & 1.6548 & 1.0419 \\
DMU32 & 1.7011 & 1.2441 & 1.3673 & DMU100 & 4.5977 & 2.0703 & 2.2207 \\
DMU37 & 0.7586 & 0.6818 & 1.1128 & DMU103 & 3.4713 & 3.0219 & 1.1487 \\
DMU42 & 1.7471 & 1.4981 & 1.1662 & DMU106 & 0.8644 & 0.2889 & 2.9923 \\
DMU43 & 0.8644 & 0.6178 & 1.3992 & DMU114 & 2.8391 & 2.3820 & 1.1919 \\
DMU48 & 1.8621 & 1.6490 & 1.1292 & DMU115 & 1.5747 & 1.4434 & 1.0910 \\
DMU51 & 1.7471 & 1.7315 & 1.0090 & DMU119 & 0.8644 & 0.8555 & 1.0104 \\
DMU53 & 1.5747 & 1.5705 & 1.0027 & DMU123 & 0.6782 & 0.6436 & 1.0537 \\
DMU56 & 2.1034 & 1.2758 & 1.6487 & DMU134 & 1.0000 & 0.7841 & 1.2754 \\
DMU62 & 2.4023 & 2.3136 & 1.0383 & DMU142 & 1.0575 & 0.9876 & 1.0707 \\
DMU64 & 1.4023 & 1.2653 & 1.1083 & DMU151 & 0.8644 & 0.6197 & 1.3948 \\
DMU65 & 2.2529 & 1.9671 & 1.1452 & DMU156 & 0.8644 & 0.5832 & 1.4821 \\
DMU68 & 2.3908 & 1.8287 & 1.3074 & DMU168 & 0.8644 & 0.6159 & 1.4034 \\
DMU69 & 3.4598 & 3.0162 & 1.1470 & DMU171 & 0.8644 & 0.7138 & 1.2109 \\
DMU70 & 2.2069 & 2.0061 & 1.1001 & DMU173 & 0.8644 & 0.6523 & 1.3252 \\
DMU71 & 2.2874 & 1.2429 & 1.8403 & DMU178 & 0.8644 & 0.6163 & 1.4025 \\
DMU78 & 1.6897 & 1.1702 & 1.4439 & & & & \\
\hline
\end{tabular}

A perusal of the table showed that only 43 $(21.5 \%)$ farms achieved a robust increase in output index. Increase in output of 12 DMUs viz.12, 22, 51, 53, 62, 82, 86, 96, 99, 115, 119 and 142 was due to increased input use which brought inefficiencies in their use. The increase in output index coupled with an almost parallel increase in inputs-use index led to near stagnant total factor productivity of rice production for these DMUs. However, the output indexes were found to be higher than the indexes of inputsuse leading to positive TFP. Furthermore, the robust increase in the output of the remaining 31 DMUs viz. 11, 21, 26, 31, 32, 37, 42, 43, 48, $56,64,65,68,69,70,71,78,87,89,100,103$, $106,114,123,134,151,156,168,171,173$ and 178 was attributed to balanced use of inputs which induced an upward shift in the production function to the extent that technological change was embodied in them. The higher output increase triggered by technological change has resulted in high positive TFP in rice production at the period of this study. For the remaining DMUs their TFP is negative i.e the farms observed decrease in their TFP as their index values are less than 1 .

\section{Factors influencing Efficiencies and TFP of Lowland Paddy Rice Farmers}

The MLE results of the factors influencing technical, cost, allocative efficiencies and total factor productive (TFP) of lowland paddy rice production are given Table 06. The diagnostic tests viz. LR Chi ${ }^{2}$ for technical (TE), cost (CE), allocative (AE) efficiencies and TFP are 34.42, 40.80, 20.10 and 44.80 respectively; and, were significant at 1, 10, 1 and $1 \%$ probability levels, respectively. The significance of the $\mathrm{LR} \mathrm{Ch}^{2}$ at less or equal to $10 \%$ probability level implies that the Tobit model is best fit and appropriate for the specified equation; and, the estimated 
coefficients in the model are different from zero. From the Pearson correlation results the presence of perfect collinearity between access to credit and co-operative membership led to the elimination of the latter variable to avoid multicollinearity and non-robustness/efficiency of the estimated coefficients. The test for multicollinearity using variance inflation factor (VIF) showed absence of multicollinearity between the independent variables included in each of the efficiencies and TFP models, the residuals.

Table 06a: MLE of Technical, Cost, Allocative Efficiencies and TFP of Lowland paddy rice farmers

\begin{tabular}{|c|c|c|c|c|}
\hline Variables & $\mathrm{TE}$ & $\mathrm{CE}$ & $\mathrm{AE}$ & TFP \\
\hline Constant & $0.78023(5.089)^{* * *}$ & $0.25203(3.762)^{* * *}$ & $0.2899(3.700)^{* * *}$ & $0.54837(2.460)^{* *}$ \\
\hline Age & $-0.00276(0.7346)^{\mathrm{NS}}$ & $-0.00033(0.1759)^{\mathrm{NS}}$ & $0.00160(0.8804)^{\mathrm{NS}}$ & $0.00319(0.6168)^{\mathrm{NS}}$ \\
\hline Marital status & $-0.11321(1.950)^{*}$ & $-0.03999(1.067)^{\mathrm{NS}}$ & $0.01975(0.6593)^{\mathrm{NS}}$ & $-0.14288(1.678)^{*}$ \\
\hline Education & $-0.01573(0.4298)^{\mathrm{NS}}$ & $-0.01085(0.550)^{\mathrm{NS}}$ & $-0.00801(0.3977)^{\mathrm{NS}}$ & $-0.01546(0.2698)^{\mathrm{NS}}$ \\
\hline Household size & $0.00169(0.5544)^{\mathrm{NS}}$ & $-0.00027(0.1827)^{\mathrm{NS}}$ & $-0.00113(0.6794)^{\mathrm{NS}}$ & $0.00186(0.3942)^{\mathrm{NS}}$ \\
\hline Farming Experience & $-0.00354(0.8187)^{\mathrm{NS}}$ & $-0.00217(1.103)^{\mathrm{NS}}$ & $-0.00155(0.6886)^{\mathrm{NS}}$ & $-0.01016(1.590)^{\mathrm{NS}}$ \\
\hline Farm size & $0.04934(3.142)^{* * *}$ & $0.03595(3.958)^{* * *}$ & $0 . .01921(2.391)^{* *}$ & $0.11483(5.042)^{* * *}$ \\
\hline Land ownership & $0.02082(0.3326)^{\mathrm{NS}}$ & $0.03595(1.658)^{*}$ & $0.04389(1.344)^{\mathrm{NS}}$ & $0.06876(0.7402)^{\mathrm{NS}}$ \\
\hline Seed variety & $-0.14639(2.389)^{* *}$ & $-0.10281(3.179) * * *$ & $-0.05295(0.7880)^{\mathrm{NS}}$ & $-0.32937(1.723)^{*}$ \\
\hline Non-farm activity & $-0.02694(0.3614)^{\mathrm{NS}}$ & $-0.01142(0.3396)^{\mathrm{NS}}$ & $-0.01273(0.3777)^{\mathrm{NS}}$ & $-0.00971(0.101)^{\mathrm{NS}}$ \\
\hline Extension contact & $-0.11772(2.165)^{* *}$ & $0.05233(1.964)^{* *}$ & $0.00544(0.1877)^{\mathrm{NS}}$ & $-0.15951(1.934)^{*}$ \\
\hline Access to credit & $0.02795(0.7684)^{\mathrm{NS}}$ & $0.01582(0.8159)^{\mathrm{NS}}$ & $0.02359(1.200)^{\mathrm{NS}}$ & $0.09903(1.771)^{*}$ \\
\hline Security & $0.09618(1.165)^{\mathrm{NS}}$ & $0.11499(1.809)^{*}$ & $0.11057(2.953)^{* * *}$ & $0.33206(3.118)^{* * *}$ \\
\hline Chi2 (12) $\left(X^{2}\right)$ & $34.415[0.00058]^{* * * *}$ & $40.795[0.000053]^{* * *}$ & $20.103[0.06516]^{* * *}$ & $44.796[0.000011]^{* * *}$ \\
\hline Normality test (2) $\left(X^{2}\right)$ & $32.054[1.0956 \mathrm{E}-007]^{* * *}$ & $40.388[1.697 \mathrm{E}-009] * * *$ & $4.109[0.1282]^{* * *}$ & $33.784[4.612 \mathrm{E}-088]^{* * *}$ \\
\hline
\end{tabular}

Source: Field survey, 2017

Note: $* * * * * * N S$ means significant at 1\%, 5\%, 10\% probability levels and non-significant respectively.

Table 06b: Elasticity of TE, CE, AE and TFP

\begin{tabular}{lccccc}
\hline \multicolumn{1}{c}{ Variables } & TE & CE & AE & TFP & $\begin{array}{c}\text { Multicollinearity test } \\
\text { (VIF*) }\end{array}$ \\
\hline Age & & & & & 5.585 \\
Marital status & -0.1756 & & & -0.18156 & 1.198 \\
Education & & & & 1.078 \\
Household size & & & & & 2.160 \\
Farming Experience & & & 0.07867 & & 5.888 \\
Farm size & 0.1492 & 0.2279 & & 0.26047 & 1.388 \\
Land ownership & & 0.1357 & & & 1.105 \\
Seed variety & -0.0060 & -0.0104 & & -0.01053 & 1.119 \\
Non-farm activities & & & & & 1.140 \\
Extension contact & -0.0269 & -0.0284 & & -0.02827 & 1.083 \\
Access to credit & & & & & 1.157 \\
Security & & 0.02356 & 0.01391 & 0.022835 & 1.077 \\
\hline
\end{tabular}

Note: * implies VIF for TE, CE, AE and TFP 
However, non-normality of residuals is not considered a serious problem because data in most cases are not normally distributed. The variables with significant influence on technical, cost, allocative efficiencies and TFP were marital status, farm size, seed variety and extension contact; farm size, ownership status, seed variety, extension contact and farm security; farm size and security; and, marital status, farm size, extension contact, access to credit and farm security, respectively. The estimated coefficients of marital status for TE and TFP exhibit inverse relationships and were all significant at $10 \%$ probability level. This implies that married farmers were more technical efficient and productive in the use of their inputs to maximize output. The marginal and elasticity implication of being single will be decrease in TE and TFP by 0.11 and 0.14 ; and, 0.176 and 0.18 respectively.

The benefit of a farmer being married is twin advantage of social and economic capital which would help them to be efficient in their farming activities. The social capital has to do with decision making-two good heads are better than one; and the economic capital is concerned with pooling of economic resources to increase the capital/investment base of their enterprise. The estimated coefficient of farm size showed direct relationships across all the dependent variables and were significant at less or equal to $10 \%$ probability level. The marginal and elasticity implications indicated that a unit increase in the farm size would increase TE, CE, AE and TFP by 0.049, 0.033, 0.019 and 0.115; and, 0.49, 0.23, 0.079 and 0.26 , respectively. The benefits of a farmer operating on a large scale are economies of scale and other pecuniary advantages. Also farmers' having large farm holdings will not be constrained to adopt innovations that are meant for large scale.

The estimated coefficient of owing a farm exhibited positive relationship with $\mathrm{CE}$ and was significant at $10 \%$ probability level. The marginal and elasticity implication of owing a farm would result in an increase in CE by 0.036 and 0.136 respectively. The advantage of owing a farm will encourage farmer to be rational in his farm investment i.e his decision on the farm would be enhanced as he becomes a better manager of farm resources for increased productivity from the set of farm inputs utilized. Also farmers who own farm land will not be constrained to adopt innovations that are meant for cash crops. The estimated coefficients of seed variety used had a negative influence on TE, CE and TFP and were significant at 5, 1 and $10 \%$ probability levels respectively.

Therefore, the marginal and elasticity implication of using local rice seed variety will lead to decrease in TE, CE and TFP by $0.15,0.10$ and 0.33 ; and, 0.006, 0.01 and 0.11 respectively. The estimated coefficients of extension contact were found to be inversely related to TE, CE and TFP, and were significant at 5, 5 and $10 \%$ probability levels. The marginal and elasticity implication of those farmers with no extension contact would be decrease in their TE, CE and TFP by $0.12,0.05$ and 0.16 ; and, $0.027,0.028$ and 0.028 , respectively. Therefore, farmers in the studied area with extension contact will be exposed and well informed about innovative farming technologies. Access to credit was found to have positive influence on TFP and was significant at $10 \%$ probability level. Therefore, farmers with access to credit will be able to procure the required quantity of farm inputs at the right time, thus, enhancing their productivity. The marginal and elasticity implication of farmers with access to credit will translate to an increase in their TFP by 0.10 and 0.083 respectively. Credit facilities has been known to be vital for food sector growth given that bulk of the food supply in the country come from scattered small land holdings cultivated by subsistence/peasant farmers. Lastly, the estimated coefficients of security had inverse relationship with $\mathrm{CE}, \mathrm{AE}$ and $\mathrm{TFP}$, and were significant at 10, 1 and $1 \%$ probability levels, respectively. It is a known fact that food security can only prevail under political, economical, social and cultural atmosphere that is devoid of rancour. Therefore, for food security to be ensured, security of lives and property must be seen as a necessity and should not 
be compromised. The marginal and elasticity implication of farm security will translate to an increase in CE, AE and TFP by $0.12,0.11$ and 0.33 ; and, $0.023,0.014$ and 0.023 , respectively.

\section{Factors Affecting Lowland Paddy Rice Farmers in the Studied Area}

Shown in Table 07 are the identified problems affecting lowland paddy rice farmers in the studied area. The identified highly severe and moderately severe problems were inadequate extension contact and poor implementation of government rice policies; and, poor road network, high cost of agro-inputs, high cost of hired labour, weak support from co-operative societies, poor market outlet, price fluctuation and insufficient credit facilities, respectively, and were given rank $1^{\text {st }}, 2^{\text {nd }}, 3^{\text {rd }}, 4^{\text {th }}, 5^{\text {th }}, 6^{\text {th }}$, $7^{\text {th }}, 8$ th and $9^{\text {th }}$ respectively. All the remaining problems were identified to be less severe problems as evident from the score shown in the Table. However, the cases of severe, undecided and non-severe problems were not observed in the studied area. In order to justify the ranks assigned to the problems, Kendall's coefficient of concordance (KCC) was calculated and the estimated coefficient was 0.55 and significant at $1 \%$ as evident from the $\mathrm{Chi}^{2}$, indicating high agreement among the farmers with respect to the ranking. Therefore, for any policy intervention, study advised compliance with this ranking in addressing the problems affecting lowland paddy rice farmers in the studied area. In order to evaluate the extent of agreement among the farmers, the Friedman's test statistic was estimated and the estimated $\mathrm{Chi}^{2}$ statistic was found to be significant at $1 \%$, meaning that the ranks assigned to the subject under investigation comes from the same statistical population.

Table 07: Constraints affecting lowland paddy rice farmers in the studied area

\begin{tabular}{|c|c|c|c|c|c|c|c|}
\hline Constraints & Mean & $\begin{array}{c}\text { Market } \\
\text { constraint }\end{array}$ & $\begin{array}{c}\text { Government } \\
\text { constraint }\end{array}$ & $\begin{array}{c}\text { Credit } \\
\text { constraint }\end{array}$ & $\begin{array}{l}\text { Instability } \\
\text { constraint }\end{array}$ & $\begin{array}{c}\text { Production } \\
\text { constraint }\end{array}$ & $\begin{array}{l}\text { Infrastructura } \\
\text { constraint }\end{array}$ \\
\hline High cost of transportation & $3.71\left(6^{\text {th }}\right)$ & 0.877 & & & & & \\
\hline Poor market outlet & $3.72\left(5^{\text {th }}\right)$ & 0.874 & & & & & \\
\hline Price fluctuation & $3.70\left(7^{\text {th }}\right)$ & 0.832 & & & & & \\
\hline Processing problem & $3.09\left(11^{\text {th }}\right)$ & 0.651 & & & & & \\
\hline Storage problem & $2.88\left(14^{\text {th }}\right)$ & 0.713 & & & & & \\
\hline Inadequate extension services & $5.94\left(1^{\text {st }}\right)$ & & 0.925 & & & & \\
\hline Flood \& Drought occurrence & $3.36\left(9^{\text {th }}\right)$ & & 0.822 & & & & \\
\hline Pest \& Diseases & $3.12\left(10^{\text {th }}\right)$ & & 0.660 & & & & \\
\hline Implementation of Govt. policy & $5.90\left(2^{\mathrm{nd}}\right)$ & & 0.946 & & & & \\
\hline Inadequate credit facilities & $3.60\left(8^{\text {th }}\right)$ & & & 0.928 & & & \\
\hline Co-operative societies problems & $3.72\left(5^{\text {th }}\right)$ & & & 0.934 & & & \\
\hline Land tenure problem & $3.06\left(13^{\text {th }}\right)$ & & & & 0.679 & & \\
\hline Communal \& herdsmen conflict & $3.07\left(12^{\text {th }}\right)$ & & & & 0.512 & & \\
\hline High cost of improved agro-inputs & $3.93\left(4^{\text {th }}\right)$ & & & & & 0.782 & \\
\hline High cost of hired labour & $3.85\left(5^{\text {th }}\right)$ & & & & & 0.744 & \\
\hline Poor road network & $4.00\left(3^{\mathrm{rd}}\right)$ & & & & & & 0.859 \\
\hline Kendall's coefficient (KCC) & 0.55 & & & & & & \\
\hline Chi2 $\left(\chi^{2}\right)$ & $1661.05^{* * *}$ & & & & & & \\
\hline Friedman's Chi2 $\left(\chi^{2}\right)$ & $1661.05^{* * *}$ & & & & & & \\
\hline Eigen-value & & 3.875 & 2.039 & 1.838 & 1.420 & 1.188 & 1.124 \\
\hline$\%$ of variance & & 24.22 & 12.75 & 11.49 & 8.87 & 7.42 & 7.03 \\
\hline Cronbach's Alpha & & 0.859 & 0.881 & 0.880 & 0.777 & 0.779 & 0.758 \\
\hline Kaiser-Meyer-Olkin test & 0.872 & & & & & & \\
\hline Bartlett's Test of Sphericity $\left(\chi^{2}\right)$ & $1291.21 * * *$ & & & & & & \\
\hline
\end{tabular}


To reduce the number of research variables and find the common factors affecting lowland paddy rice farmers in the studied area, the 16 identified problems were subjected to a factor analysis. Kaiser-Meyer-Olkin (KMO) test value of 0.872 achieved the meritorious level of sampling adequacy. Thus, the items were suitable for factor analysis, considering that a $\mathrm{KMO}$ value between 0.8 and 1 indicates that the sampling is adequate (Mansourfar, 2006). Also, the Bartlett's test rejected the hypothesis that the correlation matrix was an identity matrix (at the level of 0.01) and showed a significant relationship between the variables. A cursory review of the results revealed the six factors that were extracted from the analysis of the problems hindering lowland paddy rice production met the cut-off criterion with Eigen-values greater than 1. The estimated Cronbach's alpha value for each of the six dimensions or factors were greater than 0.7. All these provide evidence of the appropriateness of the sample for the principal components analysis. The behaviour of individual items in relation to others within the same factor provides confirmation of content validity because the highest factor loading is central to the domains assessed by these factors (Francis et al., 2000). The total variance explained by these factors was $71.78 \%$ and generally considered satisfactory in social sciences (Hair et al., 1998; 2006 as cited by Sadiq et al., 2017). The extracted factors and their respective factor loadings exclude those for which the absolute value of the loading was less than 0.40. In labeling the factors that were loaded from two factor loadings, only the higher factor score was considered. The six extracted factors were labeled as market constraint, government constraint, credit constraint, instability constraint, production constraint and infrastructural constraint.

Factor one (1) labelled market constraint has an Eigen-value of 3.88, captured five items and the most important factor as it explained $24.22 \%$ of variance of the inhibiting factors. The items of this factor point to farmers concern over poor market outlet for their products, and thus, the need for efficient market which will make them get remunerative prices for their product from the chain. Factor two (2) labelled government constraint has an Eigen-value of 2.04, captured four items and the second most important factor as it explained $12.75 \%$ of variance of the inhibiting factors. The items of this factor point to the farmers concern over poor implementation of government policies and call for monitoring and evaluation of policies to ensure efficiency of the rice value chain. The third factor (3) labelled credit constraint has an Eigen-value of 1.84, captured two items and the third most important factor because it accounted for $11.49 \%$ of variance of the inhibiting factors. The items of this factor showed farmers concern on poor credit facilities and advocate for adequate and timely delivery of credit facilities at reasonable interest rate in order to enable farmers to maximize farm profit at minimal cost level. Factor four (4) labelled instability constraint has an Eigen-value of 1.42, captured two items and it explained $8.87 \%$ variance of the inhibiting factors. The items of this factor showed farmers concern on insecurity on their lives and properties, and call for a stable environment devoid of rancour's and crises be it communal conflict, land dispute and farmers/herdsmen clash in order to achieve food security. The remaining two factors viz. production and infrastructural constraints with an Eigen values of 1.19 and 1.12 respectively, collectively explained $14.45 \%$ of variance of inhibiting factors, and both made an almost equal contribution in this respect, which points to their equal importance. The items loaded on production factor showed farmers concern on high cost of working capital and call for a review of the partial subsidy on farm operational inputs in order to enhance productivity; while the items loaded on infrastructure factor showed farmers concern on poor road network and call for adequate provision of feeder roads in order to link the farm sector with output markets which in most cases are located in the towns and cities. 


\section{CONCLUSIONS RECOMMENDATIONS \\ the poor farmers cultivating rice crops in the studied area.}

The research showed that most of the paddy rice farmers in the studied area were not smart farmers as evident from the mean efficiency estimates of technical, cost and allocative efficiencies. The TFP also showed that most of the farmers did not achieve a robust increase in output index. However, the pseudo-profit function indicated that the enterprise was found to be profitable in the studied area. Furthermore, the major factor that affects the economic efficiency and TFP of rice is the use of local seed variety. The major causal problems affecting production were institutional, economic and social. Therefore, based on this results, it can be inferred that there remained more untapped potentials in rice production in the study area. Based on these the following recommendations were made:

- Government should formulate supportive policies targeting welfare improvement of

- Stakeholders should look into the aspect of extension service delivery which is almost absent during the studying period and this explained the reason for high use of local rice seed varieties in the studied area.

- Research institutes should re-visit the technology behind the improved rice seed variety to see the reason for the poor acceptability due to past experience by the farmers.

- Policy makers should pay more emphasis on sustainable productivity as the pressure on the use of land is causing incessant rift (herdsmen/ arable crop farmer's clashes) in the country which currently threatens the relative peace in the farming community as it is causing loss of lives and properties.

\section{REFERENCES}

Banker, R.D., Charnes, A. and Cooper, W.W.(1984).Some models for estimating technical and scale inefficiencies in Data Envelopment Analysis. Management Science, 30(9):1078- 1092. DOI: http://dx.doi.org/10.1287/mnsc.30.9.1078

Charnes, A.W, Copper W. and Rhodes, E.(1978).Measuring the efficiency of decision marking units. European Journal of Operational Research, 2(1):429-444. DOI: http://dx.doi. org/10.1016/0377-2217(78)90138-8

Daily Trust Newspaper (2016).Federal Government to assist Kwara State in rice expansion. $5^{\text {th }}$ September, 2016 DOI: http://dx.doi.org/10.1787/reg_glance-2016-graph104-en

Federal Ministry of Agriculture and Rural Development (FMARD)(2001). Crop area and yield survey. DOI: http://dx.doi.org/10.1016/j.catena.2015.12.002

Federal Ministry of Agriculture and Water Resources (FMAWR)(2008). Rice production potentials in Nigeria. Annual Report, 2:33-34 DOI: http://dx.doi.org/10.4314/bja.v4i1.41928

Francis, L., Katz, Y. and Jones, S.(2000).The reliability and validity of the Hebrew version of the computer attitude scale. Computer Education,35(2):149-59. DOI: http://dx.doi.org/10.1016/ s0360-1315(00)00022-1

Friedman, M.(1937). The use of ranks to avoid the assumption of normality implicit in the analysis of variance. Journal of American Statistical Association,32(200):675 DOI: http://dx.doi. org/10.2307/2279372 
Heidari, M.D., Omid, M. and Akram, A.(2011).Optimization of energy consumption of broiler production farms using Data Envelopment Analysis Approach. Modern Applied Science, 5(3):69-78. DOI: http://dx.doi.org/10.5539/mas.v5n3p69

Kendall, M.G. and Smith, B.B.(1939).On the method of paired comparisons. Biometrica, 31(3:4):324-345 DOI: http://dx.doi.org/10.1093/biomet/31.3-4.324

Kendall, M.G. and Smith, B.B.(1939).The problem of m ranking. The Annals of Mathematical Statistics, 10(3):275-287. DOI: http://dx.doi.org/10.1214/aoms/1177732186

Khoshnevisan, B., Rafiee, S., Omid, M. and Mousazadeh, H.(2013).Comparison of GHG emissions of efficient and inefficient potato producers based on Data Envelopment Analysis. Journal of Agricultural Engineering and Biotechnology,1(3):81-88. DOI: http://dx.doi.org/10.18005/ jaeb0103005

Leadership Newspaper (2017).Rice production in Nigeria increases to 5.8 million tonnes. $18^{\text {th }}$ May, 2017 DOI: http://dx.doi.org/10.1787/641266387173

Mansourfar, K.(2006). Advanced Statistical Methods: Using Applied Software. University of Tehran Press. DOI: http://dx.doi.org/10.23943/princeton/9780691150703.003.0005

Meena, S., Singh, I.P.and Meena, R.L.(2016).Cost of cultivation and returns on different cost concepts basis of onion in Rajasthan.Economic Affairs, 61(1): 11-16. DOI: http://dx.doi. org/10.5958/0976-4666.2016.00002.4

National Bureau of statistics (NBS) (2010). Commercial agricultural development project (CADP). NBS/CADP Baseline Report, Pp. 5-46. DOI: http://dx.doi.org/10.6028/nbs.sp.360

National Population Commission (NPC) (2006). Census Report, Abuja Nigeria. DOI: http://dx.doi. org/10.21315/jps2016.27.2.5

O’Donell, C.J. (2008).An aggregate quantity-price framework for measuring and decomposing productivity and profitability change, Centre for Efficiency and Productivity Analysis, working papers WPO07/2008. University of Queensland, Queensland. DOI: http://dx.doi.org/10.1007/ s11123-012-0275-1

Punch Newspaper (2017).Rice production in Nigeria increases to 5.8 million tonnes in $2017.17^{\text {th }}$ May, 2017. DOI: http://dx.doi.org/10.1787/9789282108000-graph29-en

Sadiq, M.S., Singh, I.P., Isah, M.A., Greima, I.J. and Umar, S.M. (2017).Strategy of minimizing the cost of cultivation vis-à-vis boosting farm income of small-holder maize farmers in Niger State of Nigeria using Efficiency Measurement System (EMS). Indian Journal of Economics and Development, 17(2a):722-728. DOI: http://dx.doi.org/10.5958/2322-0430.2017.00159.7

SAHEL (2015).Rice in Nigeria: Industry dynamics. SAHEL, 12:1-3. DOI: http://dx.doi. org/10.4103/1118-8561.160803

Subba, R.S., Raghu, R.P., Neelakanta, S. T. A. and Bhavani, D.I.(2016).Agricultural Economics Second Edition. Oxford and IBH publishing company PVT. Limited, New Delhi, India. DOI: http://dx.doi.org/10.1080/07373939108916686

Tobin, J.(1958).Estimation relationship for limited dependent variables. Econometrica, 26:24-36. DOI: http://dx.doi.org/10.2307/1907382 
The Journal of Agricultural Sciences, 2018, Vol.13, No. 2

Wallis, W.A.(1939).The correlation ratio for ranked data. Journal of the American Statistical Association, 3(207):533-538. DOI: http://dx.doi.org/10.2307/2279486 